Article

\title{
Entrepreneurial Risk-Taking in Sustainable Energy: University Spin-Off Firms and Market Introduction in Northwest Europe
}

\author{
Razieh Nejabat and Marina Van Geenhuizen * \\ Faculty of Technology Policy and Management, Delft University of Technology, 2628 BX Delft, The Netherlands; \\ r.nejabat-1@tudelft.nl \\ * Correspondence: m.s.vangeenhuizen@tudelft.nl
}

Received: 4 November 2019; Accepted: 4 December 2019; Published: 5 December 2019

check for updates

\begin{abstract}
Universities are cradles of innovation, with many start-ups involved in sustainable energy solutions. The extent in which such solutions reach the market and the kind of risk-related factors young firms encounter, are hardly known and understood. We aim to clarify market introduction and focus on the empirics of firms' risk-taking behavior related to strategic choices, competences, and interactions with (national) ecosystem conditions. We use a unique dataset of almost 110 university spin-off firms and a small selected sample from this set. A total of $60 \%$ of spin-offs are able to reach the market, most of them in the first five years of spin-offs' lives. Wind energy provides the best chances, as compared to such things as solar photovoltaics (PV) and advanced biomass. In-depth results suggest the high probability of quick market introduction in 'Innovation Leader' countries, like Sweden and Denmark, if combined with employing rich collaborative networks. A second set of favorable influences includes a practical mindset and accessing substantial investment capital. In contrast, strong risks tend to be connected to activity in fundamental inventions, highly specialized technology, weakly developed (sub) markets, poorly built networks, and short refunding time of substantial investment. This study provides a unique contribution to understanding the market introduction of sustainable energy solutions and risk-taking in this effort by young high-tech firms, among others, connected to differences between countries.
\end{abstract}

Keywords: entrepreneurship; sustainable energy technology; market introduction; university spin-offs; risk-taking; competence; entrepreneurial ecosystem; Northwest Europe

\section{Introduction}

Fighting climate change, in particular greenhouse gas emissions, has become a pressing issue in recent years in the European Union, country governments, cities, universities, and businesses, as evidenced by various assessment reports and long-term strategic visions (e.g., [1-4]). Technology, both existing and emerging, is an important source of solutions, alongside knowledge on practical applications. High-tech start-up firms are increasingly seen as important actors in the (transitional) change of energy systems, as evident from the growing publication of (inter)national lists of such firms (e.g., [5,6]). Due to their involvement in developing and introducing new technology, high-tech start-ups are particularly acknowledged for their ability to develop disruptive innovations due to their willingness to 'cross borders', adopt flexibility, idealistic orientation, creativity, responsiveness, and a forward-looking attitude, and overall to take various risks that are mitigated through dynamic networking with large firms. Also, different from established (large) firms, they have no reputation to lose after been involved in mistakes [7-9].

However, literature also witnesses doubt, talks about 'potentials' and addresses the need for research agendas [10-14], and provides even clearly pessimistic views, emphasizing high risks, 
complexity, and ambiguity, connected with the energy system's resistance to change, and a broader 'liability of newness' [15-17]. A focus on the potential of high-tech start-ups in sustainable energy not only highlights developing new technology solutions and bringing them to market, but also addresses scaling-up production to enable structural change of (urban) energy systems [12]. In scaling-up solutions, once more many risks need to be taken, related to 'make or buy' decisions, channels of internationalization, and financing new activities [18].

The specific young firms' segment taken into account in the current paper, is that of university spin-off firms. In general, these firms are independent ventures established by graduates or university staff with the mission to bring novel university knowledge to market. Compared with other start-ups, they tend to lack market knowledge and practical skills in management and marketing but enjoy more benefits from university support, not only concerning technology, but also access to important additional knowledge and networks [19-23].

Only a small number of studies have addressed market introduction of sustainable energy products and processes by university spin-off firms, and this conforms to an overall weak attention to firm-specific factors and ecosystem conditions [24-27]. There are a few studies on 'drivers' or determinants of sustainability innovation and risk-taking among small firms, including firm-specific factors, and there is work that connects perceived barriers with firm profiles. However, these studies do not provide longitudinal and in-depth insights into time and ways to market; such investigations have only recently emerged [28]. Against this backdrop, this current study aims to clarify market introduction and the time involved, by exploring the influence of selected spin-off firms' risk-related factors. The questions we address can be detailed as follows: what are the patterns of market introduction, and what is the influence of risk-related factors connected to firms' strategic choice, competence, and broader interaction with business ecosystems? In addition, what may be the implication of market introduction for scaling-up the innovation?

The study draws on a representative sample of spin-offs in energy sustainability in Denmark, Finland, Norway, Sweden (Nordic countries), and the Netherlands and on a selected subsample, including a set of in-depth case studies to identify preliminary types of spin-offs with regard to firm antecedents. The justification of selecting this 'corner' of Europe, is that the innovation and competitive profiles on the country level are often strongest in the European Union; this with the exception of Norway and also the Netherlands in the past 10 to 15 years [29]. Sustainability or social entrepreneurship tends to be an early stage phenomenon [30], more so than traditional high-tech entrepreneurship, because a sustainability goal is not fully compatible with commercial goals and strategies and comes with additional risks of early failure. In selecting Denmark, Finland, and Sweden, facing highly favorable opportunities, we could focus in more detail on later stages' ways to market introduction and scaling-up, not mainly early failure. By also including representative spin-offs in Norway and the Netherlands, we inserted more differentiation in the sample.

The following empirical contribution to literature has been achieved. First, based on representative data, we observed that a small majority of university spin-off firms $(60 \%)$ reached the market and most of them at an early age (before six years) were apparently at lower risk-levels; this suggests better opportunities in wind energy and energy saving as compared to solar photovoltaics PV and advanced biomass in less established markets. Secondly, based on a qualitative study, the risk factors identified tend to stem from specific strategic choices and mainly external institutional and organizational factors, including constraints from regulation, poor arrangements in financing innovative activity, and one-sided developed firms' networking. Theoretically, the results contribute to preliminary understandings through the integration of risk-related thinking with firms' strategic choices, firm competences, and the utilization of firms' entrepreneurial ecosystems, seen from a resource-based perspective.

The paper unfolds as follows. In Section 2, sustainable energy systems and technology as well as the entrepreneurial perspective (strategic choice and competence) and the entrepreneurial ecosystem approach are discussed. This is followed by methodology, including data collection and brief principles of rough-set analysis (Section 3). In Section 4, results are presented, including patterns of market 
introduction, including age and energy technology, and sets of influencing factors and risks in market introduction, the last illustrated by six spin-off firms. Section 5 closes the paper with a reflection, indication of future research, and preliminary recommendation.

\section{Context and Theoretical Approaches}

\subsection{Context: Energy System Approach and Transition}

An energy system can be seen as a collection of interacting physical/technology elements, such as power plants, distribution grids, technology firms, metering systems, etc., but also of related social elements, including individuals, firms, governments, institutions and related regulations, standards, pricing regimes, etc. All these elements together with their strong linkages constitute the socio-technical system of energy, and partially also of transport systems (engine and fuel technology). Bringing about changes in energy systems, particularly substitution of energy sources, implicates the involvement of a large numbers of actors-on both the technical and social side-along with their networks and interconnections, and consequently a concomitant dealing with resistance to structural change or transition [31-35]. In a conceptual approach to such socio-technical systems, emphasizing comprehensiveness and complexity, three levels are distinguished, the so-called regime, landscape, and niche. The regime is the solid structure that accounts for stability in the system, and this refers to sets of rules that direct and coordinate social and economic groups in reproducing various system activities; for example, through lock-in mechanisms, in particular sunk cost impacts, vested interests, user preferences and practices, and experienced business models. The next level is the landscape (non-spatial) and this refers to broader sets of influences and environmental (external) pressures for transition. Accordingly, the landscape includes the macro-level of political cultures and national support for particular systems (e.g., in alignment with the Paris Agreement on climate change), and broader trends in macro-economic growth and technology development, thereby creating a broader context of opportunities as well as constraints to radical change.

On the lowest level of the system are the so-called niches, providing room for nurturing novel projects and for learning about market introduction (business models), adjustment in regulation, and upscaling; for example, using real-life experimentation labs and demonstration projects, outside the constraining influence of regular market forces. Niche projects are often well-organized in supporting protected learning and experimentation, eventually supporting in bridging the 'chasm' to become 'mainstream' and accomplish transition pathways [36-43]. On the firm (project) level, convincing learning results eventually achieved with local communities may support in fighting constraints and increasing legitimacy towards large firms, financial institutions, and governments, thereby enabling further investment, testing, and eventual upscaling towards larger markets [44].

Coming back to transformative change, resistance is specifically connected to the centralization in current energy systems, given the fact that renewable energy technology, such as wind and solar, particularly the last one, enables more decentralized production and consumption. Decentralized production on a small scale and in a distributed pattern, often close to where consumption is, comes with major savings for consumers, but the changes may also render part of the central grids redundant and affect the business model of central grid providers [45-49]. In addition, consumer prices may be higher compared to conventional solutions while user comfort may be lower in early years, and financial investors may have preferences accordingly. In conclusion, market introduction of sustainability technology connected to transformative change is more complicated and requires more risk-taking compared with technology without such change, in particular in a stronger mobilizing of resources with emphasis on financial ones $[48,49]$. This situation justifies the emphasis on different degrees of risk-taking and mitigation of risk in our research framework. 


\subsection{Research Framework and Operationalization}

To explore technology spin-offs' market introduction and time involved, we examine the relevant understandings of firms' antecedents with regard to risk-taking. In principle, commercial entrepreneurship is an act of risk-taking in itself [50]. However, in sustainable entrepreneurship the main goal tends to be bringing sustainability solutions quickly to market and upscaling, eventually contributing to system change, dependent among others on entrepreneurs' ambitions (emotions) or feeling for responsibility. Compared to commercial entrepreneurship, this situation introduces uncommon motivations and decisions causing earlier and more severe constraints and risks, calling for stronger awareness and proactiveness (e.g., [51,52]).

We explore a resource-based model with emphasis on competence and risk-related factors: (1) strategic choice, reflecting different degrees of risk-taking regarding use of technology, products, and markets of energy sustainability solutions (e.g., innovativeness, specialization) and two factors that enable the realization of strategic choice through resources (competence); (2) firm specific competence in terms of different awareness and understanding of risk-taking, ranging from small awareness to strategic and (proactive) dealing with risks, enabling mitigation by mobilizing additional resources; and (3) firms' interactions with the entrepreneurial environment to access additional resources that may prevent and mitigate risks, but may also be a source of new risks, like constraints from regulation (standards). Note that there may be interactions between the sets of factors (Figure 1), like between competence in networking achieved through education at university and its influence on the richness of networks (ecosystem).

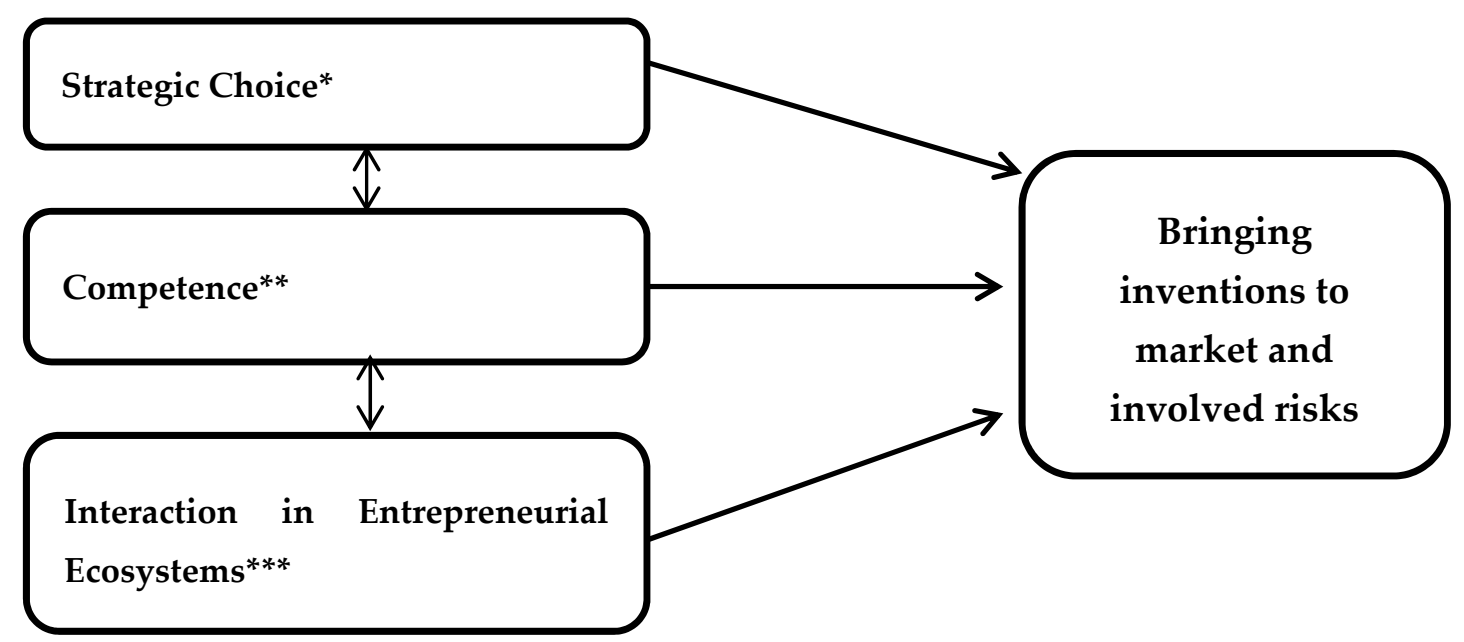

Figure 1. Research framework of risk-related firm antecedents. ${ }^{*}$ Refers to basic entrepreneurial choice and risk-taking of technology, product, and market. ${ }^{* *}$ Refers to competence in gaining resources, including awareness and knowledge on risk and risk mitigation. ${ }^{* * *}$ Refers to accessing additional resources in business ecosystems to mitigate risk, mainly through networking, but also to facing new risks, like from regulation.

\subsection{Risk-Related Strategic Choices}

Risk-taking in strategic choices is mentioned as a dimension of entrepreneurial orientation (EO) that in general refers to organizational processes, motivation, practices, and decision-making activities that firms use to act entrepreneurially. Entrepreneurial orientation as a posture reflects innovativeness, risk-taking, proactiveness, and competitive aggressiveness [53-57]. We measure risk-taking in strategic choices using the following four indicators: specific energy technology, the way of value creation, strategy archetype including first mover, followers, etc., and product/market focus or diversification [58-61], as reflected in practical business models and plans [61]. Further, the specific energy technology a firm selects comes with different risks, as some technologies have already been 
accepted in the market, like wind energy and hydropower, more than solar PV energy, though the last one as well as biomass are running up more recently [62]. Another important risk-related decision is whether to be involved in fundamental improvements, like new types of solar cells (e.g., nanomaterials for improved conversion efficiency), as opposed to incremental improvement or practical application of sustainability devices, which we name in this study 'way of value creation'. The related innovation strategy (strategy archetype) like first mover or early/late follower $[18,58]$ comes with different opportunities but also with different risks. First movers are first in the market and can take a large market share, but they may also face risk of inventions that are not yet perfect at that time, a situation providing strong opportunities to early followers to learn and improve. Finally, a main entrepreneurial decision is to remain focused on the invention (and its market) or to diversify; for example, using the same/similar technology for other products/services (platform technology), or to add services in the same market. Diversification is an important way of reducing risks if market introduction is still far away $[59,60]$ but it may also deter focal attention from the new solution, eventually increasing delay in market introduction. A slight diversification, for example with services and closely related (traditional) products, seems however not problematic; instead, it may be supportive in learning about the market (e.g., on specific customer demand and business models), and avoiding the risk of the 'the valley of death' [17].

\subsection{Risk-Related Competence}

The competence-based view posits that owning competence to make better use of resources, including identifying needs for new resources and how to acquire them, may increase competitiveness [63-65] and this has attracted a lot of attention to the composition of the founding team with regard to human capital [66-69]. In sustainability entrepreneurship competitiveness may not have first priority, but questions on whether the technology (solution) works in reality (pilots), how to position the new solution in the market (market segmentation), and the financial risks that need to be prevented may have first priority [18,52]. We prefer to highlight competence in awareness on risks, and strength of awareness ranging from low to strong awareness, the last including a proactive dealing to prevent or mitigate risk. Early and strong awareness enables the development of capabilities to acquire those resources that are needed in quickly changing situations of risk [70-74]. Most recently, in theory and practice of dynamic capabilities, attention has increased for dealing with uncertainty and risk [72]. We measure differences in competence using two indicators; first, highest education in starting teams thereby referring to more practical orientation through MSc education versus more academic orientation through a $\mathrm{PhD}$ (and often academic career), the last coming with weaker awareness on practical application of technology and business risks. The second indicator is owning a business and/or market experience by founding team members. Such experience may particularly increase early awareness about risks and risk mitigation.

\subsection{Entrepreneurial Ecosystems}

Entrepreneurial ecosystems (EES) may help in the prevention or mitigation of risks but may also be the source of (new) risks. In general, in EES thinking, small high-tech firms act in myriads of networks and relationships which are partially in close proximity (city/region), and well-developed ecosystems contribute to productivity and persistence of high-growth entrepreneurship [75-78]. Emphasis is put on institutional and organizational conditions, in particular networks that enable entrepreneurial identification and commercialization of opportunities, including outcomes on risk-taking choices. The approach is not entirely new as attention has been given to knowledge spillovers, seedbed conditions, talent, specialized services, and opportunities for competition and collaboration in earlier literature, like on regional innovation systems (RIS) and clusters [79-84]. In our framework of risk-taking, we used as indicators of interaction in entrepreneurial ecosystems (1) poor versus rich networking in gaining important resources and capabilities [9,75], (2) specifically gaining investment capital [14]. By using the first indicator we can also picture alliances with larger firms including their 
roles in launching customers and providing channels in internationalization. We also use a broad indicator at the country level (National Innovation System, NIS) (e.g., for quality of the entrepreneurship and innovation system), and group the countries accordingly.

In more detail, building and maintaining diversified networks is not an easy task, and could be a risk in itself, for example when relations with friends, family, and colleagues shift towards 'arms' lengths ones', in which business rules apply, like with energy providers, car manufacturers, battery industry, or turbine manufacturers [85-88]. In contrast, other young firm segments may easily act somewhat proactively by collaborating in niches with a diversified partner set, enabling open experimentation and demonstrating results that are convincing for policy makers and future users [89-91]. Further, gaining substantial investment is highly relevant, but often a risk among young high-tech spin-offs, particularly after first (informal) investments. Lack of capital is worrisome in next testing at a larger scale, while the spin-off fails to be sufficiently attractive for professional investors like venture capitalists and banks, causing the emergence of the 'valley of death' [17]. Such situations matter in sustainability markets that grow relatively slowly due to higher customer prices and smaller comfort as compared to accepted solutions. The risk of being affected particularly matters for firms in hardware, machinery, instruments, and new materials, who face large investment needs and eventually a quick depreciation. Supportive entrepreneurial ecosystems are seen as providing sufficient opportunities for accessing finance in a timely manner, though the question can be posed whether venture capital and more fundamental energy inventions properly match [92].

With regard to the National Innovation System (NIS), national conditions may include assets like entrepreneurial and risk-taking culture and national supportive schemes of incentives and venture capital, preventing or mitigating risks [93-98]. As indicated by countries' positions in the European Innovation Union Scoreboard [96], Norway is assigned the label of Moderate Innovator and the Netherlands that of Innovation Follower, while Denmark, Finland, and Sweden are qualified as Innovation Leaders. We mentioned that in the past years, the situation in the Netherlands has been almost similar to that of Norway, typically with a high level of scientific output but weak commercialization efforts, apparent from small firms innovating in-house, indicating a weak entrepreneurial risk-taking culture [97]. On the other hand, energy consumption and policies clearly differ between the two countries. Norway produces a huge share of sustainable energy mainly on account of hydropower, while the country exploits large oil/gas reserves mainly for exports. In contrast, in the recent past, the Netherlands was endowed with large natural gas reserves, which is in part domestically used as well as for export, in an overall strong orientation on fossil fuels [99]. Also, the Netherlands once supported innovation in wind energy, but this policy was abandoned for various years, causing emerging risks for young firms at the time involved in wind energy or planning to do so.

Another source of variation in risk-taking between countries is the institutional side of intellectual property (IP [100-102]. IP regimes may influence scientists' commitment and involvement in commercialization of inventions, such as through founding a spin-off firm $[100,101]$. Quite recently, the Nordic countries have faced a shift in ownership rights from professors (Professor Privilege) to the university, except for Sweden, (Denmark in 2000, Norway in 2003, and Finland in 2007). In Norway, the shift in ownership to the university has caused approximately a $50 \%$ decrease in the rate of starting up a firm by university researchers [100] and potentially more risk-taking among them. In addition, universities have reinforced this shift by establishing technology transfer offices (TTOs) or the like. Such developments should be taken into account in our analysis, however, the differences in years (and time-lags) involved, require a detailed exploration on individual country level which goes beyond the current study. 


\section{Methodology}

\subsection{Dataset 1: Full Sample (Descriptive Analysis)}

We composed a sample of 107 university spin-off firms active in development and market introduction of sustainable energy inventions in Northwest Europe, including the four Scandinavian countries of Denmark, Finland, Norway, and Sweden, and the Netherlands. During the data collection which took place from 2017-2018, we used multiple sources: existing in-depth interviews by the authors or other persons engaged in spin-off development at TU Delft (PhD students); firms' website presentation at different points in time; internet coverage, for example through branch journals like Nordic Green and trend studies; university websites on spin-off firms; reports/messages on firms connected to the European Institute of Innovation \& Technology Climate - Knowledge and Innovation Community EIT Climate-KIC (most recent years); annual reports of investment (venture capital) companies and consortia; and internet communication on acquisition, capital investment, and bankruptcy. These sources were used to answer a structured data list of firm antecedents of market introduction, which was cross-validated and checked by both authors (in 2018). In case of doubt, supplementary data were collected through telephone or email. The retrospective data included the following: composition of the founding team (education and experience); important events and years, namely, firm establishment, pilot projects and other testing, introduction of the invention to market, and exit; type of networks and collaborating partners, and gaining of investment capital; and a set of data on the energy technology in which the spin-off is involved, and other strategic choices including value creation, strategy archetype, and diversification (focus).

The observation period was from 1998 to 2018. The reason for selection of these years was that we wanted to understand to what extent sustainability entrepreneurship and market introduction are early stage or later stage phenomena, since emphasis in literature is on early stage [30]. Such a long period also enabled us to picture eventual upscaling of the innovation. In the data collection, we 'screened' all above-mentioned sources-particularly older years-for energy spin-offs that were founded but also closed down within this period; we identified 37 of them. However, we may have missed some of these spin-offs, potentially causing non-survival bias. For that reason, we checked whether the ones that closed down but were included in Dataset 1 were substantially different from the ones that survived up to 2018, in terms of market introduction and energy system (Appendix A). A total of 65\% of the sampled spin-offs survived in 2018, while 35\% could not survive, due to bankruptcy (13\%) or acquisition (21.5\%). As can be expected, non-survivors in our dataset face a lower share of market introduction, namely $43 \%$ as opposed to $69 \%$ among survivors. The difference is not large enough that we need to expect an important bias in our sample. In addition, simulation results-'increasing' the number of non-survivors in the sample by about $10 \%$-indicate only small differences in market introduction (Appendix A).

\subsection{Dataset 2: Selected Sample (Rough-Set Analysis)}

Using Dataset 1, we composed a selected subsample of 37 spin-off firms (Dataset 2). Different from analysis of Database 1 which aimed at representativeness in a statistical sense, analysis of the subsample made use of a conscious composition that reflects sufficient variation in theoretical positions (contrasts) as indicated in the research framework (Figure 1) with firm antecedents like country, energy technology, diversification versus focused strategy, and capabilities through experience. Of course, using a small selected sample and applying a specific 'theoretical' selection does not allow statistical generalization of the results. Instead, the approach enables 'generalization' on the basis of theoretical positions of the spin-offs [103,104], like a 'typical' combination of country and collaborative networks. Such combinations and concomitant development in market introduction are presented as so-called rules derived from rough-set analysis, and are basically preliminary, calling for further testing. In addition, the list of risk factors as derived from different 'theoretic positions' (Table 5) ought to be seen as preliminary as well. 
We applied a fuzzy-based method, rough-set analysis, to the selected subsample (Dataset 2) [105-107]. The advantages of this analysis are as follows: in contrast to traditional regression analysis, no assumption is made about a normal distribution of the data, and no emphasis is put on linear and cumulative ways of thinking. Instead, causal relations may be indicated by multiple interaction effects as expressed as combinations of conditions (rules) [108]. The procedure is stepwise. As a first step, data on each individual spin-off firm including their variables are used to compose the so-called information table, serving as a basis for a systematic analysis of the framework (Figure 1). The information table is a matrix in which spin-offs are arranged on the basis of their nine independent variables (condition attributes) and dependent variable (decision attribute). Next, the basic procedure in rough-set analysis works through attribute reduction (i.e., finding a smaller set of condition attributes with the same or close classificatory power as the original set of attributes). Further, on the basis of a reduced information table, the analysis composes decision rules in various rounds. A decision rule is presented in an 'IF condition(s) THEN decision' format.

Rough-set analysis is increasingly recognized in literature as a useful classificatory method, including elements of causal relations. This holds for example for comparing performance of firms and marketing strategies, evaluation of development of urban revitalization projects, university incubator projects, transport systems, etc., particularly when it comes to analyzing small samples and qualitative data [109-113].

\section{Patterns of Market Introduction}

\subsection{A Small Majority}

We measured market introduction as the year of first sales. For firms faced with a somewhat vague borderline between last testing and customer market by using launching customers, we include the year of main launching customer activity as indicated by the firms. Market introduction is often seen relative to age, providing an indicator of time to market. The full sample (Dataset 1 ) indicates that market introduction has been achieved by a small majority of spin-offs, 64 out of $107(60 \%)$ (Table 1). With regard to age, $70 \%$ of the spin-offs reach the market in the first five years of their life, with year 4 and 5 as the largest category $(30 \%)$. The pattern suggests more difficulty and risks in market introduction after the age of five and conversely it points to advantages of young age.

Table 1. Market introduction (MI) by age of spin-offs from 1998-2018 (Dataset 1).

\begin{tabular}{cccc}
\hline Age of MI & Frequency (abs) & Share (\%) & Cumulative Share (\%) \\
\hline $0-1$ & 14 & 21.9 & 21.9 \\
\hline $2-3$ & 12 & 18.7 & 40.6 \\
\hline $4-5$ & 19 & 29.7 & 70.3 \\
\hline $6-7$ & 8 & 12.5 & 82.8 \\
\hline $8-9$ & 8 & 12.5 & 95.3 \\
\hline $9+$ & 3 & 4.7 & 100.0 \\
\hline Total & 64 & 100.0 & \\
\hline
\end{tabular}

Sustainable energy and related transport solutions in this study encompass production and use of renewable energy sources; improved production and use of traditional sources (e.g., cleaner and more efficient); energy saving in buildings and industrial processes; and new types of energy storage (batteries). In terms of technology, we observed, for example, the use of new materials at nanoscale (solar PV, batteries) and new chemical processes (hydrogen-related), new principles in mechatronics (e.g., gearless turbines in wind and in hydro, wave and current applications), technologies that make fuel production more sustainable, like in exploration and exploitation of oil/gas (sensors, imaging) and in advanced use of biomass (membranes, sensors), new vehicle technology (fuel and engine), 
and electric vehicles and charging systems. Markets in the countries concerned in this study have quickly developed for wind energy in the past years, but solar PV and biomass have recently increased. In our analysis, we distinguished the following technologies: solar PV, wind, new vehicles, biomass related, and energy saving, the last including advanced smart lighting and/or heating in houses, offices, and industrial processes. When comparing, we observed different trends of early and late market introduction and failure in reaching the market (Table 2). Note that the numbers of spin-offs are too small for drawing solid conclusions, but we may observe a trend of best chances for early market introduction and for market introduction at all for wind energy and energy saving solutions $(69 \%$ and $64 \%$, and $75 \%$ and $79 \%$, respectively) and a trend of strikingly smaller chances for solar energy ( $32 \%$ and $46 \%$, respectively). Vehicle technology tends to be in-between. Spin-offs tend to be the least successful in bringing advanced biomass solutions early to market, including new sources like algae and new gas upgrading technology.

Table 2. Trends in age of market introduction per energy technology from 1998-2018 (Dataset 1).

\begin{tabular}{cccccc}
\hline Energy Technology & $\begin{array}{c}\text { Early (Age 0-5) } \\
\text { Introduction }\end{array}$ & $\begin{array}{c}\text { Late (Age > 5) } \\
\text { Introduction }\end{array}$ & $\begin{array}{c}\text { All } \\
\text { Introduction }\end{array}$ & $\begin{array}{c}\text { Failure in } \\
\text { Introduction }\end{array}$ & Totals \\
\hline Solar & $7(32 \%)$ & $3(14 \%)$ & $10(46 \%)$ & $12(54 \%)$ & $22(100 \%)$ \\
\hline Wind & $11(69 \%)$ & $1(6 \%)$ & $12(75 \%)$ & $4(25 \%)$ & $16(100 \%)$ \\
\hline Vehicle technology & $7(47 \%)$ & $2(22 \%)$ & $9(60 \%)$ & $6(40 \%)$ & $15(100 \%)$ \\
\hline Advanced Biomass & $2(15 \%)$ & $4(31 \%)$ & $6(46 \%)$ & $7(54 \%)$ & $13(100 \%)$ \\
\hline Energy saving & $9(64 \%)$ & $2(14 \%)$ & $11(79 \%)$ & $3(21 \%)$ & $14(100 \%)$ \\
\hline Others * & $9(33 \%)$ & $7(26 \%)$ & $16(59 \%)$ & $11(41 \%)$ & $27(100 \%)$ \\
\hline Totals & $45(42 \%)$ & $19(18 \%)$ & $64(60 \%)$ & $43(40 \%)$ & $107(100 \%)$ \\
\hline
\end{tabular}

* Includes technologies related to energy storage (batteries), hydrogen/fuel cells, wave/tidal and hydro energy, sustainable oil exploration, and exploitation.

\subsection{Microscopic Views on Positive and Problematic Development}

To explore details of positive as well as problematic or risk-full development on the way to market introduction, we turn to the selected sample of spin-off firms and rough-set analysis (Dataset 2). As a result of experimentation and robustness checks aimed at balance between classification power and detail that is redundant, we reduce the number of classes per variable mostly to two. Accordingly, value creation as an indicator of strategic choice is inserted in the rough set analysis as technology fundamentals, like gaining higher conversion efficiency of solar cells versus improving the application, like curving solar cells in roof tile shape and smart energy (saving) services. Strategy archetype is identified as 'first mover' if the solution is completely new and radical, versus 'follower' or 'customer intimate'. Diversification is determined using firms' announcements of a main additional product or substantially new services, like entering the computer screen market with thin film technology (originally for producing solar cells). Further, market/business experience is measured as the pre-start experience of one of the founders versus no experience, while technical (scientific) competence versus practical competence is indicated by the majority of $\mathrm{PhDs}$ versus merely a Master level degree. Networks are measured as stable relations focusing on resources and actor involvement, by using two classes as follows: none or few (like mainly academic research or mainly pilot-related) versus many and diverse (like investors, testing partners, customers, suppliers, etc.). Accessing substantial investment capital is indicated as small amounts or nothing versus amounts exceeding 1 million Euro. Finally, national innovation systems are included using countries' profiles in the Innovation Union Scoreboard from a few years ago (2015): Innovation Leaders (Denmark, Sweden, Finland) versus Innovation Followers or otherwise (Netherlands and Norway).

The measurement of the independent variable (decision attribute) in rough set analysis is as follows. Given the above identified five-year borderline and various robustness checks, five years after 
a firm's start is taken as the dividing line. The label positive development is assigned to a short time to market introduction (in the first five years), or (if not reached the age of five years, given limits of our observation period) a short time/successful pilot testing and favorable follow-up, while the label problematic development is assigned to firms facing a longer development/testing time, exceeding the age of five years (see Table 3). The table indicates sufficient variation in scores for most variables.

Table 3. In rough set analysis (descriptive results of selected sample, $n=37$ ).

\begin{tabular}{|c|c|}
\hline Variables & Attributes' Share \\
\hline \multicolumn{2}{|c|}{$\begin{array}{c}\text { Condition Attributes ('independent' variables) } \\
\text { Strategic Choice }\end{array}$} \\
\hline Energy technology & $\begin{array}{c}\text { Solar: } 35.1 \% \text {; Wind: } 18.9 \% \text {; Other (biofuels, fuel cells, combination, etc.): } \\
\text { 27.0\%; Automotive: } 18.9 \%\end{array}$ \\
\hline Value creation & $\begin{array}{l}\text { Core (fundamentals) of energy technology: } 67.6 \% \\
\text { Additional application of technology: } 32.4 \%\end{array}$ \\
\hline Strategy archetype & $\begin{array}{c}\text { First mover: } 35.1 \% \\
\text { Otherwise (follower/customer intimate): } 64.9 \%\end{array}$ \\
\hline Diversification/focus & Diversification: $27.0 \%$; Focus: $73.0 \%$ \\
\hline \multicolumn{2}{|r|}{ Competence } \\
\hline Market/business experience & Business experience: $56.7 \%$; No business experience: $43.3 \%$ \\
\hline Technical/practical competence & PhD: $70.3 \%$; only Master: $29.7 \%$ \\
\hline \multicolumn{2}{|r|}{ Interaction in Entrepreneurial Ecosystems } \\
\hline Developing networks & Multiple: $54.1 \%$; Otherwise (no/one-sided): $45.9 \%$ \\
\hline Accessing investment capital & No: $54.0 \%$; Yes: $46.0 \%$ \\
\hline Countries' profile in innovation & $\begin{array}{c}\text { Finland, Denmark, Sweden (Innovation Leaders): } 43.2 \% \\
\text { Norway (Innovation Follower): } 18.9 \% \\
\text { Netherlands (Innovation Follower): } 37.8 \%\end{array}$ \\
\hline \multicolumn{2}{|r|}{ Decision Attribute ('dependent' variable) } \\
\hline $\begin{array}{l}\text { Development in bringing } \\
\text { inventions to market }\end{array}$ & Positive: $59.5 \%$; Problematic: $40.5 \%$ \\
\hline
\end{tabular}

The rough set procedure leads to 11 rules, of which we showed the eight strongest (Table 4). It is worth noticing that we used the following quality checks of the rough-set procedure and outcomes (Appendix B). The first step is the determination of condition attributes in the 'core', namely those ones with the strongest classification power. These turn out to be energy technology, richness of networks (single/multiple), and countries' innovation profile. The quality of classification of attributes in the core is 0.84 , which is below the maximum of 1.0 but still acceptable, whereas the quality of classification of all condition attributes is 1.0. Next, a validation of the rules is performed by using $\mathrm{K}$-fold cross-validation. This is a method to evaluate predictive models by randomly partitioning the sample into K subsamples in which one of them acts as a validation set for testing the model and the rest of the K-1 subsamples are put together to form a training set [111]. The results have a sufficient level of accuracy (almost 70\% in total) for obtained decision rules (Appendix B). 
Table 4. Rules on bringing energy inventions to market.

\begin{tabular}{|c|c|c|c|c|}
\hline & Rules as Combinations of Condition Attributes * & $\begin{array}{c}\text { Decision } \\
\text { Attribute }\end{array}$ & $\underset{* * *}{\text { Coverage }}$ & $\begin{array}{c}\text { Strength } \\
\% * * * *\end{array}$ \\
\hline \multicolumn{5}{|c|}{ Positive Development } \\
\hline 1 & $\begin{array}{c}\text { Country (Innovation Leader) and employing } \\
\text { multiple networks }\end{array}$ & Positive & 11 & 50.0 \\
\hline 2 & Practical competence and gaining investment capital & Positive & 7 & 31.8 \\
\hline 3 & $\begin{array}{c}\text { Energy technology (wind) and strategy archetype } \\
\text { (Follower) }\end{array}$ & Positive & 6 & 27.3 \\
\hline 4 & $\begin{array}{l}\text { Energy technology (vehicle/fuel) and developing } \\
\text { multiple networks }\end{array}$ & Positive & 5 & 22.7 \\
\hline 5 & $\begin{array}{l}\text { Energy technology (advanced technology) and } \\
\text { country (Innovation Leader) }\end{array}$ & Positive & 4 & 18.2 \\
\hline \multicolumn{5}{|c|}{ Problematic Development } \\
\hline 6 & $\begin{array}{l}\text { Energy technology (solar PV) and employing a } \\
\text { single network and strategy archetype (follower) }\end{array}$ & Problematic & 7 & 46.7 \\
\hline 7 & $\begin{array}{l}\text { Country (Norway) and maintained focus and } \\
\text { scientific competence (PhD) }\end{array}$ & Problematic & 4 & 26.7 \\
\hline 8 & $\begin{array}{l}\text { Energy technology (other sustainable energy) and } \\
\text { country (Netherlands) and value creation (core) }\end{array}$ & Problematic & 3 & 20.0 \\
\hline
\end{tabular}

${ }^{*}$ Relatively weak rules (strength lower than $15 \%$ ) are not shown. There is some overlap between the identified rules (causing the total number of spin-offs covered by the rules being larger than the total sample size (37)). ${ }^{* *}$ 'Dependent' variable as positive/negative development in bringing inventions to market. ${ }^{* * *}$ Absolute number of cases covered by a rule (similar value of 'dependent' and 'independent' variables). ${ }^{* * * *}$ Share of such cases in all cases with the same value of the 'dependent' variable. Source: Adapted from [113].

Further, in determining the importance of the decision rules, we used strength and coverage. The strength of a decision rule indicates the share of all spin-off firms displaying the same combination of condition attributes (rules) and decision attribute, in all spin-offs with the same value of the decision attribute. Rough-set analysis works by learning, meaning that after various rounds the optimum number of rules becomes apparent as a balance between useful detail and redundant information. In the final results presented here (Table 4 ) the highest strength reached was $50 \%$ with a coverage (absolute number of spin-offs involved) of 11.

We now discuss the strongest rules, first the ones concerning a positive development and a strength of at least $15 \%$ (Table 4 ):

- Rule 1 indicates that the combination of operating in an Innovation Leader country (Denmark, Finland or Sweden) and employing multiple networks makes a positive development towards the market very likely, at a strength of $50 \%$. It points to a combined positive influence of the entrepreneurial ecosystem, regarding favorable national institutions and policy support together with employing rich networks.

- Similar, but weaker (at a strength of $32 \%$ ), Rule 2 indicates that the combination of mainly a Master's level as the highest education of founders and gaining substantial investment capital, makes a positive development to market likely. As assumed, a more practical and less academic/scientific orientation tends to be an advantage.

- Somewhat weaker (at $27 \%$ ), Rule 3 indicates that the combination of wind energy technology and being a follower in the market makes a positive development likely. The rule points to a positive impact from taking smaller risks as a follower in an already more or less established market.

- Likewise (at 23\%), Rule 4 indicates that the combination of automotive fuel technology and developing multiple networks makes a positive development likely. This rule puts an emphasis 
on the benefits of multiple networks in a situation of potential resistance from established automotive technology.

- Rule 5 (at low strength) indicates that spin-offs dealing with more advanced or radical energy technologies still have a chance to face a positive development if established in an Innovation Leader country.

The rise of a problematic development is more difficult to understand as it appears from a somewhat lower strength of the rules and combinations of often three condition attributes. We discuss the strongest rules (at strength of at least 15\%: Rules 6 to 8 ) as follows:

- Regarding Rule 6, the combination of solar PV technology, a poor collaboration network, and acting as follower, makes a problematic development likely, at a strength of $47.5 \%$. It suggests that despite taking smaller risks (as follower) strong network collaboration is required in bringing solar energy solutions to market, also referring to competition from large Chinese solar cell producers active in Europe at a relatively low customer price.

- Rule 7 is less strong (at $27 \%$ ) and indicates that spin-offs in Norway, with a strong focus and high scientific skills $(\mathrm{PhD})$ are likely to develop in a problematic way. This rule suggests problematic risks in basic research and in maintaining focus and scientific orientation. Such spin-offs may face the 'valley of death' or they may have gained substantial investment capital in time, however, at a too short refunding period.

- Finally, Rule 8 (at 20\%) indicates that spin-offs in the Netherlands engaged in technology, such as fuel cells and alternative biomass (algae) in more basic (core) research, are likely to develop in a problematic way. Such spin-offs tend to be engaged with pilot plants and larger scale testing for a longer time, thereby requiring substantial financial investment (and eventually face the 'valley of death').

We summarize the above outcomes as trends in theoretical positions as follows. First, the selected energy technology is most prominently present in rules on positive and problematic developments. Secondly, interaction with the entrepreneurial ecosystem tends to have a strong influence on positive development as witnessed by the prominent presence in the strongest rules: country NIS, developing multiple networks, and accessing investment capital. By contrast, a problematic development happens more often as a result of combinations of negatively working risk-related choices, such as those involved in the fundamentals of a technology.

\subsection{Microscopic Views on Risk Factors}

We address trends in risk factors and the time these tend to emerge on the way to market (Table 5), derived from our qualitative studies. We tentatively conclude that most risk factors are connected to specific strategic choices and potential failure in firm-ecosystem interaction, mainly in later testing. The last ones refer to institutional and organizational risks, for example, dealing with pressure from regulation and refunding conditions, and the inability to build fertile networks. In our data, we observe spin-offs that take risks but are able to prevent negative impacts by 'counter-acting', like in intensive experimentation in niches, or adding a limited set of related products/services to gain cash flow, while other spin-offs take risks but cannot prevent negative impacts. We also observe ones that avoid risk-taking, like in being active in services and an established market. The list in Table 5 is preliminary because of the partial character of the framework (firm antecedents) and the limited number of case studies; in addition, some risk factors tend to overlap by acting on different levels (broader, more specific). 
Table 5. Preliminary list of risk factors faced by spin-offs.

\begin{tabular}{|c|c|c|}
\hline $\begin{array}{c}\text { Firms' } \\
\text { Antecedents }\end{array}$ & Specification of Firms' Risk Factors & Emergence \\
\hline \multirow{6}{*}{ Strategic choice } & Involved in solar PV and other more advanced technologies & All times \\
\hline & Acting as first mover & All times \\
\hline & Involved in fundamental solutions & All times \\
\hline & Involved in highly specialized technology and small markets & Defining the market \\
\hline & Hurried market introduction at lower quality innovation & $\begin{array}{l}\text { Later testing and } \\
\text { market introduction }\end{array}$ \\
\hline & $\begin{array}{l}\text { Not active in services or traditional products (while needed to } \\
\text { avoid the valley of death) }\end{array}$ & $\begin{array}{l}\text { Later testing } \\
\text { (extended pilot) }\end{array}$ \\
\hline \multirow{3}{*}{ Competence } & Missing practical competence and orientation & All times \\
\hline & Poor preparation by founders (easy-going mentality) & Early testing \\
\hline & Poor signaling of emerging competition & All times \\
\hline \multirow{7}{*}{$\begin{array}{l}\text { Entrepreneurial } \\
\text { ecosystems (EE) } \\
\text { interaction }\end{array}$} & $\begin{array}{l}\text { Lack of institutional-level benefits (incentives) from sustainable } \\
\text { energy (national policy) and from large firms }\end{array}$ & All times \\
\hline & Lack of investment capital (loans/venture capital) & Later testing \\
\hline & Short refunding time of substantial loans/venture capital & Later testing \\
\hline & Missing opportunities to experiment in niches (poor networks) & Later testing \\
\hline & Poor collaboration networks with large firms, policymakers, etc. & Later testing \\
\hline & Limiting regulation, for example public safety and combustion & Later testing \\
\hline & Poor warning for emerging competition & All times \\
\hline
\end{tabular}

\subsection{Illustration with Case Studies}

We discuss six spin-offs to illustrate the main trends as represented by early/late market introduction, conditions in relatively strong rules, and risk factors (a summary is in Table 6).

Case study 1 (Sweden, established in 2012) represents a positive development towards market introduction, in particular Rule 1 . With its revolutionary vertical and partly floating wind turbines on sea, market introduction has not been reached yet but seems very close, as there are many positive signs like successful testing in full sea (2015) and gaining financial capital through quotation (stock market). The networking is quite diverse including an alliance for implementation, collaboration with a German multinational and supplier of components, financial investors from wind energy and offshore/marine operations, electricity firms (distributors), etc. The spin-off is currently preparing the construction of a commercial wind turbine system near the coast of Norway. At the same time, to avoid risk from pressure of early refunding, the spin-off started to create revenue by entering into collaborations concerning a broader application of renewable energy, like in fish-farming. Overall, the development time of the invention after firm start was five/six years. 
Table 6. Summary of case studies (observed up to 2017).

\begin{tabular}{|c|c|c|c|c|c|c|}
\hline & $\begin{array}{l}\text { 1. Vertical Wind } \\
\text { Turbine }\end{array}$ & $\begin{array}{l}\text { 2. Sun } \\
\text { Simulator }\end{array}$ & $\begin{array}{l}\text { 3. EV* } \\
\text { Charging }\end{array}$ & $\begin{array}{l}\text { 4. Wind Farm } \\
\text { Services }\end{array}$ & $\begin{array}{l}\text { 5. Solar Panel } \\
\text { Application }\end{array}$ & 6. Biogas Membrane \\
\hline $\begin{array}{l}\text { MI (market } \\
\text { introduction) } \\
\text { and rules }\end{array}$ & $\begin{array}{c}\text { Planned MI } \\
\text { Rule 1: } \\
\text {-Sweden } \\
\text {-Rich networking }\end{array}$ & $\begin{array}{c}\text { Early MI } \\
\text { Rule 2: } \\
\text {-Master level } \\
\text {-Sufficient } \\
\text { Investment }\end{array}$ & $\begin{array}{c}\text { Early MI } \\
\text { Rule 2: } \\
\text {-Substantial } \\
\text { investment } \\
\text {-Master level }\end{array}$ & $\begin{array}{c}\text { Early MI } \\
\text { Rule 3: } \\
\text {-Wind energy } \\
\text {-Follower }\end{array}$ & $\begin{array}{c}\text { No MI } \\
\text { Rule 6: } \\
\text {-Solar } \\
\text {-Single networks } \\
\text {-Follower }\end{array}$ & $\begin{array}{c}\text { Early MI } \\
\text { Rule 7: } \\
\text {-Norway } \\
\text {-PhD level } \\
\text {-Focus }\end{array}$ \\
\hline Founded in & 2012 & 2011 & 2005 & 2009 & 2011 & 2008 \\
\hline Invention & $\begin{array}{c}\text { Vertical and } \\
\text { floating (cost-saving) }\end{array}$ & $\begin{array}{l}\text { Solar cell testing at } \\
\text { highest accuracy }\end{array}$ & $\begin{array}{l}\text { Quick vehicle } \\
\text { charging }\end{array}$ & $\begin{array}{l}\text { Integrated, high } \\
\text { efficiency }\end{array}$ & $\begin{array}{c}\text { Construction of panels in } \\
\text { open space }\end{array}$ & $\begin{array}{c}\text { Efficient and clean gas } \\
\text { upgrade }\end{array}$ \\
\hline Profile path & Positive & Positive & Positive & Positive & Problematic & 'Borderline' \\
\hline Networks & Multiple & Multiple & Multiple & Multiple & Single & Multiple \\
\hline (Potential) risk factors & $\begin{array}{l}\text {-Fundamental } \\
\quad \text { solution } \\
\text {-Early refunding }\end{array}$ & $\begin{array}{l}\text {-Strong specialization } \\
\text { with small market }\end{array}$ & $\begin{array}{l}\text {-Short in funding } \\
\text {-Lack of learning } \\
\text { (experiments) }\end{array}$ & n. a. & $\begin{array}{c}\text {-Poor preparation } \\
\text {-No credibility } \\
\text {-Poor network } \\
\text {-Regulation } \\
\text {-Lack of national support }\end{array}$ & $\begin{array}{c}\text {-Academic orientation } \\
\text {-Regulation } \\
\text {-Pressure of refunding } \\
\text {-Hurried market } \\
\text { introduction }\end{array}$ \\
\hline \multicolumn{7}{|l|}{ Timeline } \\
\hline $\begin{array}{l}\text { First main investment } \\
\text { (amount) }\end{array}$ & 2016 (stock market) & $\begin{array}{c}2014 \\
\text { (reasonable) }\end{array}$ & $\begin{array}{l}\text { 2008-2010 } \\
\text { (substantial) }\end{array}$ & $\begin{array}{l}\text { No main } \\
\text { investment } \\
\text { (limited) }\end{array}$ & $\begin{array}{l}\text { No main investment } \\
\text { (limited) }\end{array}$ & 2010 (substantial) \\
\hline Pilot success & $2015 / 16$ & 2012 & From 2008 on & Not known & Limited & 2013 \\
\hline MI ** & Prepared in 2017/18 & $\begin{array}{l}2012 \text { (launching } \\
\text { customers) }\end{array}$ & 2009 & 2010 & Not applicable & 2013 \\
\hline $\mathrm{SCU} * * *$ & Not yet & 2014,2016 & 2010 & Not selected & Not possible & Limited \\
\hline State end of 2017 & $\begin{array}{l}\text { Preparation large } \\
\text { scale application }\end{array}$ & $\begin{array}{l}\text { Scaling-up in global } \\
\text { markets }\end{array}$ & $\begin{array}{c}\text { Acquired } \\
\text { Scaling-up by } \\
\text { multinational } \\
\text { company (MNC) }\end{array}$ & $\begin{array}{c}\text { Increasing } \\
\text { innovativeness }\end{array}$ & Closed down in 2013 & Closed down in 2014 \\
\hline
\end{tabular}

${ }^{*} \mathrm{EV}=$ electric vehicles; ${ }^{* *} \mathrm{MI}=$ market introduction; ${ }^{* * *} \mathrm{SCU}=$ scaling-up (global markets). 
Case study 2 (Netherlands, established in 2011) represents a positive development towards market introduction, in particular Rule 2. The spin-off is involved in testing equipment for solar PV; first, mainly for sales to universities and research institutes, later on for solar cell manufacturers and users. The product is an improved innovation, namely, an 'artificial' sun (simulator) working at the highest level of accuracy. To avoid risk from strong specialization, the firm is also involved in related products like testing equipment of influence of weather conditions on solar cells and related services, but only to a limited extent. The spin-off employed substantial diversity in domestic networks as evidenced by collaboration with the local university, research institutes, and firms as testing partners. In addition, using an investment relationship, the spin-off acquired a US-based firm, which avoided the risk of a small market (due to strong specialization) by increasing the market both regarding customer segments and geographic location. In addition, substantial investment was accessed once, in 2014, when the innovative product was already in the market. Furthermore, the spin-off's management is practically oriented and also benefits from an MBA education (one founder). Time to market was short in this case study, namely, two years. Currently the spin-off is attempting to increase global scaling-up, for example in the Far East.

Case study 3 (Netherlands, established in 2005) developed hardware and software for charging stations for electrical vehicles, with a focus on reducing charging time without causing damage to the battery. This spin-off also represents a positive development (Rule 2), equally suggesting the importance of a practical orientation and gaining substantial investment capital, the last through different financial investors, including foreign (Canada) and Dutch venture capitalists, and a battery company (Taiwan). Remarkably, the firm also showed the ability to organize and benefit from national pilots and niche experimentation, and to learn from practice together with important actors, among others a local multinational company (MNC). However, the firm failed to collect sufficient investment capital—or it missed the willingness to do so-after market introduction in the next step of global scaling-up (US and China) and decided to be acquired by the local MNC with which it already collaborated. Accordingly, scaling-up takes place within the MNC. Time to market was relatively short with four years, while survival time was six years.

Case study 4 (Finland, established in 2009) represents a positive development and Rule 3, indicating importance of a low-risk follower strategy-as a service provider-in a more or less established energy market (wind power). The firm developed a novel integrated approach to wind energy exploitation and was engaged in preparation and management of wind farms on land, including the spatial lay-out of wind turbines. To increase efficiency, the firm started to outsource specialized services. Accordingly, there was no need for substantial capital investment. Market introduction took place in 2010, only one year after firm foundation. The firm steadily increased its market share in Finland, but decided not to further extend scaling-up and invested in research and development (R\&D) to improve the efficiency of wind farms.

Case study 5 (Netherlands, established in 2011) represents an absence of market introduction, in particular Rule 6, suggesting a negative influence of being active in solar energy as a follower, while missing multiple collaboration networks (and credibility). The firm designed a novel support system (construction) for solar panels covering public spaces, like open-air parking places. However, in the next steps it started to face regulation obstacles from construction rules and safety protection in public places, at the same time that no large firm in the Netherlands was interested in producing solar energy. However, large firms in the US were seriously interested in the support system, but the spin-off was two years old and employed only two persons, and accordingly it failed to gain sufficient credibility in time. When collaboration was established with a large firm, it was too late. The spin-off closed down without having received substantial investment capital and without reaching the market. The basic risk factor was an easy-going mentality without solid preparation prior to firm start concerning regulatory issues in construction and public safety. Another, external risk factor was the weak attention in the domestic market (Netherlands) for solar energy at the time. 
Case study 6 (Norway, established in 2008) represents early market introduction while facing problematic aspects, specifically indicated by Rule 7 . We would qualify this case study as 'borderline'. The product is an advanced carbon membrane serving to upgrade biogas into biofuel (cars, busses) in a cheaper and cleaner way. The founders' competence was mainly at the PhD level and they took the risk to maintain their academic setting and orientation (scientific publications). Important collaboration (e.g., pilot testing with food industry and waste treatment) was established later on, but this could not prevent the delay (caused by environmental regulation) that slowed down market introduction. At the same time, pressure from refunding large amounts of capital (about four million Euro) was increasing. Nevertheless, market introduction of the membrane followed relatively quickly, probably at a somewhat low quality level of the membrane. This situation was the background of liquidation of the spin-off in 2014. As the spin-off is a joint venture with the university, it is plausible that research on membranes can be continued at university. All in all, market-introduction was at age five while the spin-off reached only the age of six. The following risk-factors were identified: involved in fundamental solutions, too strong of an academic orientation, difficulty and delay in responding to regulation, short refunding time of debt with a (somewhat) hurried market introduction.

We close with a final word on scaling-up and market introduction. The case studies suggest the following scenarios: market introduction is followed by scaling-up; market introduction is not followed by scaling-up due to an alternative strategic choice, namely investing in R\&D; and finally, market introduction is also not followed by scaling-up due to bankruptcy and eventually acquisition of the spin-off (unless an acquiring firm takes the decision of scaling-up).

\section{Discussion}

Among young university spin-off firms in Northwest Europe, market introduction of energy inventions is accomplished by a small majority $(60 \%)$ and in most cases before the age of six. This pattern suggests less risk at a young age, contrary to [15], but in line with learning advantages of young age, eventually including those on risk mitigation [7]. Market introduction is also influenced by the energy technology involved, with solar PV facing more difficulty in early years compared to wind energy and energy-saving. Further, the combination of being active in an 'Innovation Leader' country and employing rich networks provides the best position for a quick market introduction, and this is followed by a combination of practical business orientation (as opposed to scientific/academic orientation) and accessing substantial investment capital. In more detail, risk factors tend to be most often connected to strategic choices and institutions and organization (networking), including, among others, poor national policy, unfavorable refunding agreements connected to substantial loans (financial sector), and limitations from regulations concerning emission safety and safety in public places. As concerns of scaling-up of the new energy technology by spin-off firms, we may draw the preliminary conclusion that upscaling is not a self-understanding next step after market-introduction. Three circumstances tend to hamper scaling-up by spin-offs, namely acquisition, bankruptcy, and an alternative strategic choice. Empirical results like these are a rather novel contribution of our study to the literature. Theoretically, the study confirms preliminary understandings about first, spin-off firms' antecedents with emphasis on risk-related strategic choices (energy technology) (e.g., [62]); secondly, team competence at the start from education level (e.g., [65]); and thirdly, interaction with the regional and national entrepreneurial ecosystem, particularly in employing poor versus rich networks. The institutional and organizational (networking) elements in entrepreneurial ecosystems turn out to provide important risks if interaction remains weak and one-sided. So far, this has received small attention in empirical and theoretical studies of entrepreneurial ecosystems, making our study also novel in this respect.

Further, after exploration of the preliminary research framework which had an emphasis on firms' antecedents, we admit that in the next research steps stronger attention should be paid to (1) market dynamics in the sense of emerging risks from global competition (e.g., by low-cost producers of sustainable products/processes), and (2) risks from constraining regulation and arrangements, 
which were already addressed in the current study, but these risks require more understanding, specifically how small firms can deal with them. The need for separate attention to market dynamics in the framework is motivated by our results on solar PV spin-offs that suffered from competition by relatively cheaply imported Chinese cells and panels. The need for stronger attention for regulation (and arrangements) is motivated by our results on constraints to new combustion processes and new construction in the public space, but also in payback regimes following substantial financial loans. Remarkably, with regard to spin-offs' competences, as included in the framework, against expectations, our results indicate that experience of founders does not play an important role. This may stem from the situation that most spin-off entrepreneurs at the time of firm start had no substantial experience with application of the specific energy technologies and specific markets, which were new. If experienced, they had general business experience which tended not to matter. In addition, the research framework we used was static and calls for a more dynamic approach. For example, the timeline of important changes (or events) (e.g., a move to diversification and extension of founding team competences by adding a marketing specialist and influence on time of market introduction), has remained 'under the radar', but can be investigated in the next step, thereby using event history analysis [114].

Important parts of our results are preliminary, originating from qualitative research, and these call for attention to statistical generalization in the next steps of the study. Accordingly, the influence of firm antecedents in risk-related factors, as well as scaling-up will be subject to solid testing using our larger database. In addition, it is useful to increase understanding of the circumstances that are beneficial at university and broader in Denmark, Finland, and Sweden; for example, the nurturing of more basic inventions for a longer time at university before establishing a firm, among others dependent upon shifts in universities' rules on intellectual ownership (patents) and new incentives to compensate scientists for 'loss of IP' (e.g., [101]).

With regard to policy making and management by incubators (or spin-offs themselves), we can make the following tentative recommendation aimed at reduction of particular risks [115-117]. Firstly, adding an experienced business manager from outside to a founding team where PhDs are the majority; and secondly, on the institutional side, negotiation of more soft conditions of receiving substantial venture capital or loans, with special attention to refunding time that starts later or lasts longer, thereby reducing risks of too early market introduction and potential bankruptcy. Specific venture capital for sustainable ventures has already been developed but may require adjustments to national conditions [14]. Thirdly, promotion of early collaboration in multiple networks, preferably including a larger firm for joint development and design, and for eventual internationalization. A final point is prevention of risk from delaying impact from unforeseen rules and regulations. Particularly in sectors faced with slow procedures, real-life testing of technology solutions needs to take place at an early time, eventually in a protected environment (testbeds) at a university campus where regulatory barriers and solutions including adjusting the invention or adjusting regulation can be learned $[118,119]$. Overall, it appears that incubation support and training need to prepare spin-offs prior and during start to create early awareness and to better identify risk factors and dealing with them. This seems particularly true if the aim is transformative entrepreneurship, calling for substantial impacts in making the energy systems more sustainable, despite the system's resistance to change. Even in a small region of Northwest Europe, differentiation in such support and training is required dependent upon the entrepreneurial ecosystems' features.

Author Contributions: Data preparation, modeling, outcomes, and interpretation, R.N.; paper structured and interpretation streamlined, M.V.G.

Funding: This research received no external funding.

Acknowledgments: This research has benefitted from presentation and comments by the second author at the Workshop From startup to scale-up -Entrepreneurship, human capital, innovation and scaling up new businesses, October 29-30, 2018 (Swedish Entrepreneurship Forum).

Conflicts of Interest: The authors declare no conflicts of interest. 


\section{Appendix A. Simulation}

Table A1. Actual survival and market introduction (till 2018).

\begin{tabular}{cccc}
\hline Survival till 2018 & Market Introduction & No Market Introduction & Totals \\
\hline Survived & $48(68.6 \%)$ & $22(31.4 \%)$ & $70(100 \%)$ \\
\hline Not survived & $16(43.2 \%)$ & $21(56.8 \%)$ & $37(100 \%)$ \\
\hline Totals & $64(59.8 \%)$ & $43(40.2 \%)$ & $107(100 \%)$ \\
\hline
\end{tabular}

Table A2. Simulated (italic) by increasing number of non-surviving firms.

\begin{tabular}{cccc}
\hline Survival till 2018 & Market Introduction & No Market Introduction & Totals \\
\hline Survived & $48(68.6 \%)$ & $22(31.4 \%)$ & $70(100 \%)$ \\
\hline Not survived & $21.6(43.2 \%)$ & $28.4(56.8 \%)$ & $50 *(100 \%)$ \\
\hline > Totals & $69.6(58.0 \%)$ & $50.4(41.6 \%)$ & $120(100 \%)$ \\
\hline \multicolumn{4}{c}{$* 50: 13$ cases added }
\end{tabular}

Table A3. Survival and energy technology.

\begin{tabular}{cccccccc}
\hline $\begin{array}{c}\text { Survival till } \\
\mathbf{2 0 1 8}\end{array}$ & Solar PV & Wind & $\begin{array}{c}\text { Vehicle } \\
\text { Techn. }\end{array}$ & $\begin{array}{c}\text { Adv. } \\
\text { Biomass }\end{array}$ & $\begin{array}{c}\text { Energy } \\
\text { Saving }\end{array}$ & Others & Totals \\
\hline Survived & $13(18.6 \%)$ & $11(15.7 \%)$ & $6(8.6 \%)$ & $7(10.0 \%)$ & $11(15.7 \%)$ & $22(31.4 \%)$ & $70(100 \%)$ \\
\hline Not survived & $9(24.3 \%)$ & $5(13.5 \%)$ & $9(24.3 \%)$ & $6(16.2 \%)$ & $3(8.1 \%)$ & $5(13.5 \%)$ & $37(100 \%)$ \\
\hline Totals & $22(20.6 \%)$ & $16(15 \%)$ & $15(14 \%)$ & $13(12.1 \%)$ & $14(13.1 \%)$ & $27(25.3 \%)$ & $107(100 \%)$ \\
\hline
\end{tabular}

If we simulate that the sample includes around 10 per cent more non-survivors and assume that the market introduction rate of the additional non-survivors is similar to the market introduction rate we measured for non-survivors in our current sample (43.2 per cent), the overall market introduction rate would not be 59.8 but 58.0 per cent. Further, non-survival tends to be relatively strong among solar PV and vehicle technology, but there is no reason to assume that a large number of such spin-offs has remained beyond our scope. Our conclusion is that altogether there is no reason for concern about non-survivor bias.

\section{Appendix B.}

Appendix B.1. Rough Set Analysis: Core Determination and Quality of Classification (Dataset 2)

The core in rough-set analysis indicates the certain condition attributes necessary to explain a feature of the decision attribute. The quality of classification for attributes in the core in this study equals 0.84 which is acceptable. Also, the overall quality of classification and the accuracy of two classes equal 1.0.

Table A4. Quality indicators of the rough-set procedure.

\begin{tabular}{ll}
\hline Quality of classification for & 1.00 \\
- All condition attributes & 0.84 \\
\hline - Condition attributes in the core (3) & \\
\hline Quality of classification (two classes) & 1.00 \\
- Accuracy of approximation of positive outcomes & 1.00 \\
\hline situation & \\
\hline
\end{tabular}




\section{Appendix B.2. K-Fold Validation Test}

In our test, the cross-validation process [111] was repeated 50 times using 'training sets'. The final results prove sufficient accuracy (almost 70\% in total) for the obtained rules, and also indicate somewhat higher accuracy for rules concerning positive development compared to problematic development.

\section{References}

1. United Nations. Summary of the Paris Agreement. 2015. Available online: https://unfccc.int (accessed on 29 May 2019).

2. IPCC. Climate Report, Global Warming of $1.5^{\circ}$. 2018. Available online: https://www.ipcc.ch (accessed on 29 May 2019).

3. European Commission. An EU Strategy on Adaptation to Climate Change. 2013. Available online: https://eur-lex.europe.eu (accessed on 29 May 2019).

4. European Commission. Going Climate-Neutral by 2050. A Strategic Long-Term Vision for a Prosperous, Modern, Competitive and Climate-Neutral EU Economy; DG for Climate Action: Brussels, Belgium, 2019.

5. Crunchbase. Renewable Energy Start-Ups. Available online: https://crunchbase.com (accessed on 21 November 2019).

6. StartupDelta. Startup Solutions Energy Transition. Available online: https://www.startupdelta.org (accessed on 21 November 2019).

7. Teixeira, A.A.C.; Coimbra, C. The determinants of the internationalization speed of Portuguese university spin-offs: An empirical investigation. J. Int. Entrep. 2014, 12, 270-308. [CrossRef]

8. Gulati, R.; DeSantola, A. Start-Ups That Last: How to Scale Your Business. Harv. Bus. Rev. 2016, 94, 54-61.

9. Rothaermel, F.T.; Deeds, D.L. Alliance type, alliance experience, and alliance management capability in high-technology ventures. J. Bus. Ventur. 2006, 21, 429-460. [CrossRef]

10. Hockerts, K.; Wüstenhagen, R. Greening Goliaths versus emerging Davids-Theorizing about the role of incumbents and new entrants in sustainable entrepreneurship. J. Bus. Ventur. 2010, 25, 481-492. [CrossRef]

11. Boons, F.; Lüdeke-Freund, F. Business models for sustainable innovation: State-of-the-art and steps towards a research agenda. J. Clean. Prod. 2013, 45, 9-19. [CrossRef]

12. Burch, S.; Andrachuk, M.; Carey, D.; Frantzeskaki, N.; Schroeder, H.; Mischkowski, N.; Loorbach, D. Governing and accelerating transformative entrepreneurship: Exploring the potential for small business innovation on urban sustainability transitions. Environ. Sustain. 2016, 22, 26-32. [CrossRef]

13. Wiesbrod, I.; Bocken, N.P.M. Developing sustainable business experimentation capability-A case study. J. Clean. Prod. 2017, 142, 2663-2676. [CrossRef]

14. Bocken, N.M.P. Sustainable venture capital—Catalyst for sustainable start-up success? J. Clean. Prod. 2015, 63, 1-12. [CrossRef]

15. Freeman, J.; Carroll, G.R.; Hannon, M.T. The liability of newness: Age dependence in organizational death rates. Am. Sociol. Rev. 1983, 48, 692-710. [CrossRef]

16. Cantamessa, M.; Gatteschi, V.; Perboli, G.; Rosano, M. Startups' Roads to Failure. Sustainability 2018, 10, 2346. [CrossRef]

17. Auerswald, P.E.; Branscomp, L.M. Valleys of Death and Darwinian Seas: Financing the invention to innovation transition in the United States. J. Technol. Transf. 2003, 28, 227-239. [CrossRef]

18. Mohr, J.; Sengupta, S.; Slater, S. Marketing of High-Technology Products and Innovations, 3rd ed.; Pearson: Harlow, UK, 2013.

19. Pirnay, F.; Surlemont, B.; Nlemvo, F. Toward a typology of university spin-off firms. Small Bus. Econ. 2003, 21, 355-369. [CrossRef]

20. Shane, S. Academic Entrepreneurship: University Spin-Offs and Wealth Creation; Edward Elgar: Cheltenham, UK, 2004.

21. Vohora, A.; Wright, M.; Lockett, A. Critical junctures in the development of university high-tech spin-out companies. Res. Policy 2004, 33, 147-175. [CrossRef]

22. Walter, A.; Auer, M.; Ritter, T. The impact of network capabilities and entrepreneurial orientation on university spin-off performance. J. Bus. Ventur. 2006, 21, 541-567. [CrossRef] 
23. Van Geenhuizen, M.; Soetanto, D.P. Academic spin-offs at different ages: A case study in search of obstacles to growth. Technovation 2009, 29, 671-681. [CrossRef]

24. Bjørnali, E.S.; Ellingsen, A. Factors Affecting the Development of Clean-tech Start-Ups: A Literature Review. Energy Procedia 2014, 58, 43-50. [CrossRef]

25. Triguero, A.; Moreno-Mondéjar, L.; Davia, M. Drivers of different types of eco-innovation in European SMEs. Ecol. Econ. 2013, 92, 25-33. [CrossRef]

26. Pacheco, D.A.; Schwengber-ten Cate, C.; Jung, C.F.; Duarte-Ribeiro, J.L.; Navas, H.; Cruz-Machado, V. Eco-innovation determinants in manufacturing SMEs: Systematic review and research directions. J. Clean. Prod. 2017, 142, 2277-2287. [CrossRef]

27. Marin, G.; Marzucchi, A.; Zoboli, R. SMEs and barriers to Eco-innovation in the EU: Exploring different firm profiles. J. Evol. Econ. 2015, 25, 671-705. [CrossRef]

28. Gross, R.; Hanna, R.; Gambhir, A.; Heptonstall, P.; Speirs, J. How long does innovation and commercialisation in the energy sectors take? Historical case studies of the timescale from invention to widespread commercialisation in energy supply and end use technology. Energy Policy 2018, 123, 682-699. [CrossRef]

29. Fagerberg, J.; Fosaas, M. Innovation and Innovation Policy in Nordic Regions; University of Oslo: Oslo, Norway, 2014.

30. Hoogendoorn, B.; Van der Zwan, P.; Thurik, R. Sustainable Entrepreneurship: The Role of Perceived Barriers and Risks. J. Bus. Ethics 2019, 157, 1133-1154. [CrossRef]

31. Geels, F.W. Ontologies, socio-technical transition (to sustainability), and the multilevel perspective. Res. Policy 2010, 39, 495-510. [CrossRef]

32. Geels, F.W. Regime Resistance against Low-Carbon Transitions: Introducing Politics and Power into the Multi-Level Perspective. Theory Cult. Soc. 2014, 31, 21-40. [CrossRef]

33. Smith, A.; Voss, J.-P.; Grin, J. Innovation studies and sustainability transitions: The allure of the multilevel perspective and its challenges. Res. Policy 2010, 39, 435-448. [CrossRef]

34. Geels, F.W. The multi-level perspective on sustainability transitions: Response to seven criticisms. Environ. Innov. Soc. Transit. 2011, 1, 24-40. [CrossRef]

35. Geels, F.W. A socio-technical analysis of low-carbon transitions: Introducing the multi-level perspective into transport studies. J. Transp. Geogr. 2012, 24, 471-482. [CrossRef]

36. Lopolito, A.; Morone, P.; Sisto, R. Innovation niches and socio-technical transitions: A case study of bio-refinery production. Futures 2011, 43, 27-38. [CrossRef]

37. Smith, A.; Raven, R. What is protective space? Reconsidering niches in transition to sustainability. Res. Policy 2012, 41, 1025-1036. [CrossRef]

38. Quitzau, M.; Hoffmann, B.; Elle, M. Local niche planning and its strategic implications for implementation of energy-efficient technology. Technol. Forecast. Soc. Chang. 2012, 79, 1049-1058. [CrossRef]

39. Raven, R.; Kern, F.; Verhees, B.; Smith, A. Niche construction and empowerment through socio-political work. A meta-analysis of six low carbon technology cases. Environ. Innov. Soc. Transit. 2016, 18, 164-180. [CrossRef]

40. Dóci, G.; Vasileiadou, E.; Petersen, A.C. Exploring the transition potential of renewable energy communities. Futures 2015, 66, 85-95. [CrossRef]

41. Markard, J.; Wirth, S.; Truffer, B. Institutional dynamics and technology legitimacy. A framework and a case study on biogas technology. Res. Policy 2016, 45, 330-344. [CrossRef]

42. Dijk, M.; De Kraker, J.; Hommels, A. Anticipating Constraints on Upscaling from Urban Innovation Experiments. Sustainability 2018, 10, 2796. [CrossRef]

43. Ruggiero, S.; Martiskainen, M.; Onkila, T. Understanding the scaling up of community energy niches through Strategic Niche Management Theory: Insights from Finland. J. Clean. Prod. 2018, 170, 581-590. [CrossRef]

44. Pinkse, J.; Groot, K. Sustainable Entrepreneurship and Corporate Political Strategy. Overcoming Market Barriers in the Clean Energy Sector. Entrep. Theory Pract. 2015, 39, 633-654. [CrossRef]

45. Alanne, K.; Saari, A. Distributed energy generation and sustainable development. Renew. Sustain. Energy Rev. 2006, 10, 539-558. [CrossRef]

46. European Parliament. Economic and Scientific Policy, Decentralized Energy Systems. 2010. Available online: http://www.europarl.europa.eu/document/activities/cont/201106/20110629ATT22897/ 20110629ATT22897EN.pdf (accessed on 30 December 2017).

47. Kaundinya, D.; Balachandra, P.; Ravindranath, N. Grid-connected versus stand-alone energy systems for decentralized power-A review of literature. Renew. Sustain. Energy Rev. 2009, 13, 2041-2050. [CrossRef] 
48. Leete, S.; $\mathrm{Xu}, \mathrm{J} . ;$ Wheeler, D. Investment barriers and incentives for marine renewable energy in the UK: An analysis of investor preferences. Energy Policy 2013, 60, 866-875. [CrossRef]

49. Karltorp, K. Scaling up Renewable Energy Technologies. The Role of Resource Mobilization in the Growth of Technological Innovation Systems; Chalmer University of Technology: Gothenburg, Sweden, 2014.

50. Shane, S.; Venkataraman, S. The promise of entrepreneurship as a field of research. Acad. Manag. Rev. 2000, 5, 217-226. [CrossRef]

51. Glaeser, E.L.; Shleifer, A. Not-for-profit entrepreneurs. J. Public Econ. 2001, 81, 99-115. [CrossRef]

52. Haugh, H. A resource-based perspective of social entrepreneurship. In International Perspectives on Social Entrepreneurship; Robinson, J.A., Mair, J., Hockert, K., Eds.; Palgrave MacMillan: New York, NY, USA, 2009; pp. 99-116.

53. Lumpkin, G.T.; Dess, G. Clarifying the Entrepreneurial Orientation Construct and Linking It to Performance. Acad. Manag. Rev. 1996, 21, 135-172. [CrossRef]

54. Covin, J.G.; Lumpkin, G.T. Entrepreneurial orientation theory and research: Reflections on a needed construct. Entrep. Theory Pract. 2011, 35, 855-872. [CrossRef]

55. Dai, L.; Maksimov, V.; Gilbert, B.A.; Fernhaber, S.A. Entrepreneurial orientation and international scope: The differential roles of innovativeness, pro-activeness and risk-taking. J. Bus. Ventur. 2014, 29, 511-524. [CrossRef]

56. Shan, P.; Song, M.; Ju, X. Entrepreneurial orientation and performance: Is innovation speed a missing link? J. Bus. Res. 2016, 69, 683-690. [CrossRef]

57. Roper, S.; Tapinos, E. Taking risks in the face of uncertainty: An exploratory analysis of green innovation. Technol. Forecast. Soc. Chang. 2016, 112, 357-363. [CrossRef]

58. Lieberman, M.B.; Montgomery, D.B. First mover (dis)advantages: Retrospective and link with the resource-based view. Strateg. Manag. J. 1998, 19, 1111-1125. [CrossRef]

59. Chang, Y.; Thomas, H. The Impact of Diversification Strategy on Risk-Return Performance. Acad. Manag. Proc. 1987, 1, 2-6. [CrossRef]

60. Miller, D.J. Technological Diversity, Related Diversification and Firm Performance. Strateg. Manag. J. 2006, 27, 601-619. [CrossRef]

61. Schaltegger, S.; Lüdeke-Freund, F.; Hansen, E.G. Business models for sustainability: A co-evolutionary analysis of sustainable entrepreneurship, innovation and transformation. Organ. Environ. 2016, 29, 264-289. [CrossRef]

62. IEA (International Energy Agency). Market Report Series: Renewables 2018. Analysis and Forecasts to 2023; IEA: Paris, France, 2018.

63. Barney, J.B.; Clark, D.N. Resource Based Theory: Creating and Sustaining Competitive Advantage; Oxford University Press: Oxford, UK, 2007.

64. Freiling, J.; Gersch, M.; Goeke, C. On the Path towards a Competence-based Theory of the Firm. Organ. Stud. 2008, 29, 1143-1164. [CrossRef]

65. Rasmussen, E.; Mosey, S.; Wright, M. The influence of university departments on the evolution of entrepreneurial competences in spin-off ventures. Res. Policy 2014, 43, 92-106. [CrossRef]

66. Clarysse, B.; Moray, N. A process study of entrepreneurial team formation: The case of a research-based spin-off. J. Bus. Ventur. 2004, 19, 55-79. [CrossRef]

67. Colombo, M.G.; Grilli, L. Founders' human capital and the growth of new technology-based firms: A competence-based view. Res. Policy 2005, 34, 795-816. [CrossRef]

68. Visintin, F.; Pittino, D. Founding team composition and early performance of university-based spin-off companies. Technovation 2014, 34,31-43. [CrossRef]

69. Diánez-González, J.-P.; Camelo-Ordaz, C. How management team composition affects spin-offs' entrepreneurial orientation: The mediating role of conflict. J. Technol. Transf. 2016, 41, 530-557. [CrossRef]

70. Zahra, S.A.; Sapienza, H.J.; Davidsson, P. Entrepreneurship and Dynamic Capabilities: A Review, Model and Research Agenda. J. Manag. Stud. 2006, 43, 917-955. [CrossRef]

71. Teece, D.J. Explicating dynamic capabilities: The nature and microfoundations of (sustainable) enterprise performance. Strateg. Manag. J. 2007, 28, 1319-1350. [CrossRef]

72. Teece, D.J.; Leih, S. Uncertainty, innovation and dynamic capabilities. Calif. Manag. Rev. 2016, 58, 5-12. [CrossRef] 
73. Teece, D.J. The foundations of enterprise performance: Dynamic and ordinary capabilities in an (economic) theory of firms. Acad. Manag. Perspect. 2014, 28, 328-352. [CrossRef]

74. West, G.P.; Noel, T.W. The impact of knowledge resources on new venture performance. J. Small Bus. Manag. 2009, 47, 1-22. [CrossRef]

75. Spigel, B. The Relational Organization of Entrepreneurial Ecosystems. Entrep. Theory Pract. 2015, 41, 49-72. [CrossRef]

76. Hayter, C.S. A trajectory of early-stage spinoff success: The role of knowledge intermediaries within an entrepreneurial university ecosystem. Small Bus. Econ. 2016, 47, 633-656. [CrossRef]

77. Acs, Z.J.; Stam, E.; Audretsch, D.B.; Connor, A. The lineages of the entrepreneurial ecosystem approach. Small Bus. Econ. 2017, 49, 1-10. [CrossRef]

78. Feld, B. Start-Up Communities: Building an Entrepreneurial Ecosystem in Your City; John Wiley \& Sons: Hoboken, NY, USA, 2012.

79. Duranton, G.; Puga, D. Nursery cities: Urban diversity, process innovation, and the life cycle of products. Am. Econ. Rev. 2001, 91, 1454-1477. [CrossRef]

80. Gordon, I.R.; McCann, P. Innovation, agglomeration and regional development. J. Econ. Geogr. 2005, 5, 523-543. [CrossRef]

81. Iammarino, S.; McCann, P. The structure and evolution of industrial clusters: Transactions, technology and knowledge spillovers. Res. Policy 2006, 35, 1018-1036. [CrossRef]

82. Cooke, P. Regional Knowledge Economies: Markets, Clusters and Innovation; Edward Elgar: Cheltenham, UK, 2007.

83. Fritsch, M.; Storey, D. Entrepreneurship in a Regional Context-Historical Roots and Recent Developments. Reg. Stud. 2014, 48, 939-954. [CrossRef]

84. Florida, R.; Adler, P.; Mellander, C. The City as innovation machine. Reg. Stud. 2017, 51, 86-96. [CrossRef]

85. Lavie, D. The competitive advantage of interconnected firms: An extension of the resource-based view. Acad. Manag. Rev. 2006, 31, 638-658. [CrossRef]

86. Milanov, H.; Fernhaber, S. When do domestic alliances help ventures abroad? Direct and moderating effects from a learning perspective. J. Bus. Ventur. 2014, 29, 377-391. [CrossRef]

87. Hite, J.M.; Hesterly, W.S. The evolution of firm networks: From emergence to early growth of the firm. Strateg. Manag. J. 2001, 22, 275-286. [CrossRef]

88. Steinmo, M.; Rasmussen, E. The interplay of cognitive and relational social capital dimensions in university-industry collaboration: Overcoming the experience barrier. Res. Policy 2018, 47, 1964-1974. [CrossRef]

89. Prahalad, C.K.; Ramaswamy, V. Co-creation experiences: The next practice in value creation. J. Interact. Mark. 2004, 18, 6-14. [CrossRef]

90. Hermans, F.L.P.; Apeldoorn, D.F.; Stuiver, M.; Kok, K. Niches and networks: Explaining network evolution through niche formation processes. Res. Policy 2013, 42, 613-623. [CrossRef]

91. Tummers, L.C. Learning from Co-Housing Initiatives-Between Passivhaus Engineers and Active Inhabitants. Ph.D. Thesis, TU Delft, Delft, The Netherlands, 2017.

92. Gaddy, B.; Sivaram, V.; O'Sullivan, F. Venture Capital and Cleantech. The Wrong Model for Clean Energy Innovation; MIT Energy Initiative Paper; MIT: Cambridge, MA, USA, 2016.

93. Lundvall, B.-Á. National Innovation System-Analytical Concept and Development Tool. Ind. Innov. 2007, 14, 95-119. [CrossRef]

94. Grilli, L.; Mrkajic, B.; Latifa, G. Venture Capital in Europe. Small Bus. Econ. 2018, 51, 393-410. [CrossRef]

95. Thornton, P.; Ribeiro-Soriano, D.; Urbano, D. Socio-cultural factors and entrepreneurial activity. Int. Small Bus. J. 2011, 29, 105-118. [CrossRef]

96. EC (European Commission). Innovation Union Scoreboard; Publication Office EU: Luxembourg, 2015.

97. Van Geenhuizen, M. From Ivory Tower to Living Lab. Accelerating the Use of University Knowledge. Environ. Plan. C (Gov. Policy) 2013, 31, 1115-1132. [CrossRef]

98. Horbach, J. Determinants of environmental innovation-New evidence from German panel data sources. Res. Policy 2008, 37, 163-173. [CrossRef]

99. IEA (International Energy Agency). Countries and Regions. 2019. Available online: https://www.iea.org/ countries (accessed on 24 April 2019). 
100. Hvide, H.; Jones, B.F. University Innovation and the Professor Privilege, University of Bergen (No) and Kellog, Nortwestern University (US). 2017. Available online: https://www.kellogg.northwestern.edu/faculty/ jones-ben (accessed on 20 November 2019).

101. Van Dongen, P.; Yergos, A.; Tijssen, R.; Claassen, E. The relationships between university IP regimes, scientists' motivation and their engagement with research commercialization in Europe. Available online: http://ejlt.org/article/view/567/755 (accessed on 5 December 2019).

102. Muscio, A.; Quaglione, D.; Ramaciotti, L. The effects of university rules on spin-off creation: The case of academia in Italy. Res. Policy 2016, 45, 1386-1396. [CrossRef]

103. Mayring, P. On Generalization in Qualitatively Oriented Research. Forum Qual. Res. 2007, 8, 1-7.

104. Eisenhardt, K.M.; Graebner, M. Theory Building from Cases: Opportunities and Challenges. Acad. Manag. J. 2007, 50, 25-32. [CrossRef]

105. Pawlak, Z. Rough Sets: Theoretical Aspects of Reasoning about Data; Kluwer: Dordrecht, The Netherlands, 1991.

106. Polkowski, L.; Skowron, A. Rough Sets in Knowledge Discovery 1: Methodology and Applications (Studies in Fuzziness and Soft Computing); Springer: Heidelberg, Germany, 1998.

107. Kłopotek, M.A.; Marciniak, M.; Mykowiecka, A.; Penczek, W.; Wierzchoń, S.T. (Eds.) Intelligent Information Systems. New Approaches; Wyd. Akademii Podlaskiej: Siedlce, Poland, 2010.

108. Fiss, P.C. Building better causal theories: A fuzzy set approach to typologies in organization research. Acad. Manag. J. 2011, 54, 393-420. [CrossRef]

109. Dimitras, A.I.; Slowinski, R.; Susmeyer, R.; Zopaounides, C. Business failure prediction using rough sets. Eur. J. Oper. Res. 1999, 144, 263-280. [CrossRef]

110. Nijkamp, P.; Van der Burch, M.; Vindigni, G. A Comparative Institutional Evaluation of Public-Private Partnerships in Dutch Urban Land-Use and Revitalisation Projects. Urban Stud. 2002, 39, 1865-1880. [CrossRef]

111. Chen, W. Analysis of a customer satisfaction survey using Rough Sets theory: A manufacturing case in Taiwan. Asia Pac. J. Mark. Logist. 2009, 21, 93-105. [CrossRef]

112. Taheri, M.; Van Geenhuizen, M. Teams' boundary spanning capacity at university: Performance of technology projects in commercialization. Technol. Forecast. Soc. Chang. 2016, 111, 31-43. [CrossRef]

113. Nejabat, R.; Taheri, M.; Scholten, V.; Van Geenhuizen, M. University spin-offs steps in commercialization of sustainable energy inventions in Northwest Europe. In Cities and Sustainable Technology Transitions; Van Geenhuizen, M., Holbrook, J.A., Taheri, M., Eds.; Edward Elgar: Cheltenham, UK, 2018; pp. 59-87.

114. Vermunt, J.K.; Moors, J. Event History Analysis. In Encyclopedia of Statistics in Behavioural Science; Wiley Online Library: Hoboken, NJ, USA, 2005.

115. Mas-Verdú, F.; Ribeiro-Soriano, D.; Roig-Tierno, N. Firm survival: The role of incubators and business characteristics. J. Bus. Res. 2015, 68, 793-796. [CrossRef]

116. Vedula, S.; Kim, P.H. Gimme shelter or fade away: The impact of regional entrepreneurial ecosystem quality on venture survival. Ind. Corp. Chang. 2019, 28, 827-854. [CrossRef]

117. Van Geenhuizen, M.; Ye, Q. Responsible innovators: Open networks on the way to sustainability transitions. Technol. Forecast. Soc. Chang. 2014, 87, 28-40. [CrossRef]

118. Weishut, J. Personal Interview about On-Campus Field-Labs with One of the Authors; Delft University of Technology: Delft, The Netherlands, 2018.

119. Naber, R.; Raven, R.; Kouw, M.; Dassen, T. Scaling-up sustainable energy innovations. Energy Policy 2018, 110, 342-354. [CrossRef]

(C) 2019 by the authors. Licensee MDPI, Basel, Switzerland. This article is an open access article distributed under the terms and conditions of the Creative Commons Attribution (CC BY) license (http://creativecommons.org/licenses/by/4.0/). 